\title{
РОЗВИТОК ТРАДИЦІЙ, ЗВИЧАЇВ І ПОЧАТКІВ ЕТИКЕТУ РІЗНИХ ВЕРСТВ УКРАЇНСЬКОГО НАСЕЛЕННЯ ХVII СТ.
}

\begin{abstract}
Анотація: У статті висвітлено традиції, звичаї та початки етикету різних верств українського населення XVII cm. в аспекті розкриття націотворчого потениіалу українства. В обгрунтуванні шляхетних українознавчих нарисів франиузького інженера-картографа Гійома де Боплана показано тогочасний побут населення. Охарактеризовано особливості господарського шику еліти тогочасного суспільства Галичини. Розкрито тенденції розвитку гайдамащько-козацької субкультури. Описано ментальний портрет української інтелігенція, який уособлював сукупність традиції, звичаї та культурологічні тендениії різних верств українського населення XVII cm.
\end{abstract}

Ключові слова: традиції, звичаї, етикет українського населення, XVII ст., побут козацької старшини, церковна еліта, світський етикет Галичини

\section{Вступ.}

Традиції, звичаї та етикет є самобутніми феноменами культури, що торкаються всієї гами почуттів людини та нетлінного збагачення самого народу. Їх роль у суспільстві завжди була дуже велика, що підтверджується його тривалою історичною і соціальною еволюцією у розвитку української культури. Найперші згадки про традиції, звичаї та початки етикету серед селян і міщан XVII ст. залишив іноземний мандрівник Павло Алеппський. У виданні «Путешествие антиохийскаго патриарха Макария в Россию в половине XVII века. Описанное его сыном архидиаконом Павлом Алеппским» він описав специфіку життя українців-русинів і московитів від Дністра до Москви. Серед іншого, автор занотував елементи побуту українських монастирів, зауважуючи, що у монастирських келіях було прийнято ставити довгі лави та столи, як у традиції української хати, а також печі 3 гарно розмальованими кахлями та каптурі ${ }^{1}$.

За спостереженнями сирійця, архідиякона Павла Алеппського (близько 1627 р. 30 січня 1669 р.), його батько, патріарх Антіохійський Макарій при зустрічі підніс гетьману Богдану Хмельницькому кращого гатунку горілку у срібному кубку. Тоді ж наїдки до столу подавали у розписаних глиняних тарелях. Тобто частування у цей час вже набуває елементів прийому, і займає важливу частину етикету спілкування знатних людей.

П. Алеппський засвідчував, що у побуті козацької старшини багато сундуків зі сріб-

\footnotetext{
•Городинська Лілія Станіславівна - аспірантка Вінницького державного педагогічного університету імені Михайла Коцюбинського (м. Вінниця, Україна); ORCID: https://orcid.org/0000-0003-3440-9755; e-mail: horodynska_liliia@ukr.net

${ }^{1}$ Павел Алеппский. Путешествие Антиохийского Патриарха Макария в Россию в половине XVII века, описанное его сыном, архидиаконом Павлом Алеппским (по рукописи Московского главного архива М-ва иностранных дел). Вып. 4: Москва, Новгород и путь от Москвы до Днестра / Пер. с араб. Г. Муркоса. Общество истории и древностей российских при Московском университете. Москва, 1898. 220 с.
} 
ним посудом, хоча у походах ними не користуються. Відтоді для транспортування кришталевого, срібного та дешевшого олов'яного посуду часто вживалися спеціальні сундуки, дорожні шкатулки і погрібці (дорожні сундучки із напоями та наїдками) ${ }^{2}$. Один 3 них, аналог сучасного бару для перевезення штофів із різними видами вин, зберігається у збірці львівського Музею етнографії та художнього промислу. Розкіш і добробут у середовищі козацької старшини XVII-XVIII ст. часто вимірювалися наявністю срібних чарок, посудин, кришталевих креденців для горілки, що набувалися у боях або як особливі дарунки від титулованих, передусім, монарших осіб ${ }^{3}$.

Мета дослідження. Спираючись на доробок попередників, широку джерельну базу та сучасні методологічні підходи, метою статmі є комплексне висвітлення традицій, звичаїв і початків етикету різних верств українського населення XVII ст. в аспекті розкриття націотворчого потенціалу українства.

\section{Шляхетні українознавчі нариси французького інженера-картографа Гійома де Боплана.}

3 середини XVII ст. французький інженер-картограф Гійом де Боплан здійснив подорож землями етнічної України-Руси. Від кінця 1630 р., як інженер військових споруд і картограф, шляхтич, що був родом з французької Нормандії, Г. де Боплан працював на запрошення гетьмана Конєцпольського у м. Барі на сучасній Вінниччині. Значну увагу він приділяв опису звичаїв, традицій, церемоніалу, етикету та протоколу українців кінця XVII - початку XVII ст. Також він зазначав, що на цих землях панував інтелектуальний сарматизм. Переймаючись модним у тогочасній Европі XV ст. пошуком історичних коренів, шляхтичі вважали, що є нащадками сарматів - іраномовних племен, які мешкали на півдні сучасної України і були витіснені готами у другому сторіччі. Популярність козаччини внаслідок Хотинської битви та ї̈ військовий потенціал породжували спроби «інтелектуальної приватизації» та «націоналізації» козацтва не тільки в Касіяна Саковича та його учнів, але й серед інших польських публіцистів ${ }^{4}$.

Шлях потенційного залучення козацтва до ширшої подібної ідентичності проходив через ідеологію польського сарматизму. «Сарматський» тип портрету запорізького козака можна легко визначити за гербами, пишними підписами на картинах і певну площинність форм. Вже за часів держави Війська Запорозького, «сарматський» тип портрету буде популярним і серед козацької еліти XVII ст. Особливим атрибутом українського козака був пояс, оздоблений дорогими каменями і навіть золотом. Зимою серед сарматів були популярні натуральні хутра з рисі або ведмедя. Жінки одягалися так само багато. Основними елементами жіночої моди був корсет, розширена до низу спідниця та головний убір.

Сарматизм, що був притаманний польській шляхті, як ідеологія досить швидко розквіт і серед козаків. «Українські сармати» любили бесідувати. Їх прийняття тривали по кілька годин. До кожного гостя була приставлена дитина, яка мала йому прислужувати. Їжа була дуже жирна, а порції надзвичайно великі. Їли сало, м’ясо, рибу, каші, вареники,

\footnotetext{
${ }^{2}$ Павел Алеппский. Путешествие Антиохийского Патриарха Макария в Россию...

${ }^{3}$ Яворницький Д. Історія запорозьких козаків. У 3-х т. Т. 2. Київ: Наук. думка. 1990. 557 с.

${ }^{4}$ Кресін Олексій. Український хозаризм // Мала енциклопедія етнодержавознавства. Київ: Генеза, 1996. С. 166167.
} 
десерти, після чого починалося розпивання трунків і тости. «Сармати» багато часу та грошей присвячували моді. Їхнє вбрання відрізнялося від того, яке існувало в Європі. Щодня мужчини ходили у жупанах $з$ довгими та вузькими рукавами. Жупани для урочистих подій «на вихід», були зшиті з дорогих ексклюзивних тканин таких як атлас чи шовк червоного, рожевого чи синього кольорів.

Конфесіалізація образу лицаря у творчості Шимона Старовольського 5 знаменувала різкий відхід від попередніх спроб польських публіцистів трактувати козаків, насамперед, як братів-християн, до чого долучилася позиція козацтва в обороні православ'я, яка ускладнювала будь-які спроби залучити козацтво до нової моделі польської політичної нації.

Про Київ Гійом де Боплан писав, що місто було на першу половину XVII ст. доволі купецьким, церковна еліта складалася з єпископа, який контролював православні приходи, а також три інші храми - римські та грецькі (очевидно, малися на увазі костели бернардинів, домініканців і протестантська церква). Віра основного загалу киян була грецькою, що місцевою мовою називалася руською ${ }^{6}$.

Серед інших шанованих громадян де Боплан називає, по-суті, тільки старосту (воєводу), війта, городничого та каштеляна, тобто людей, що перебували на військовочиновничій службі. Іншу категорію складали «великодушні люди», що іменувалися запорозькими козаками. Місцеві мешканці також шанобливо ставилися до консулів і лавників, що торгували різним крамом - хутром, тканинами, сіллю, хлібом, збіжжям, салом, соленою рибою, воском, медом, коминами тощо ${ }^{7}$.

На кінець XVII - XVIII ст. вирізнявся етикет спілкування різних верств населення (обрядова, майданна та сміхова мова). Особливо вирізнялися традиційні святкові обороти та примовки, пов'язані із ритуалами гостин (ходили тільки дорослі без дітей), пригощання, почастунків.

Урочистими були проведення ініціацій - переходу з одного стану в інший: народини, хрестини, пострижини, заручини, весілля, поховання тощо. Традиційні хліб-сіль на столі, краще місце для шанованого гостя, подарунки-віддарунки, тепер доповнилися зміною місця для дружини (сідала праворуч від чоловіка). Звичайні гостини закінчувалися частуванням, святкові - трапезою ${ }^{8}$.

Їжа козаків на XVII ст. здебільшого була невибаглива, і складалася з саламахи - рід рідкої страви з вареного проса та розрідженої у воді муки, із додаванням пшона. Їли її 3 невеличких дерев'яних корит нашвидкуруч. 3 напоїв вживали брагу, медовуху, квас, горілку (горівку), рідше - пиво, тільки на свята - вино. Серед фруктів - розводили вишню, 3поміж горіхів - мигдаль. Рибу консервували у попелі, солі, варили раків.

За польськими першоджерелами середини XVII ст. (1638 р.) знаємо, що перша

\footnotetext{
${ }^{5}$ Bielak Fr. Działalność naukowa Szymona Starowolskiego. B кн.: Studia i materiały z Dziejów Nauki Polskiej. T. 5. zesz. 1. Warszawa, 1957.

${ }^{6}$ La Description d'Ukranie de Gullaume Le Vasseur de Beauplan / Edition annotée par Dennis F. Essar et Andreu B. Pernal. Ottawa; Paris; Londres: Les Pressed de l'Université d'Ottawa. 1990. XIII, 154 p. (Études Ukrainiennes de l'Université d'Ottawa; N 11).

${ }^{7}$ La Description d'Ukranie de Gullaume Le Vasseur de Beauplan...

${ }^{8}$ Йосипенко С.Л. Духовна культура України XVII - першої половини XVIII століть (історико-філософський аналіз): автореф. дис.... д-ра філософ. наук: 09.00.05. Інститут філософії імені Г.С. Сковороди Національної академії наук України. Київ, 2009. 28 с.
} 
страва завжди мала бути у щоденному меню, незалежно від того, планувалося застілля чи ні. На друге гостям готували великий шмат каплуна (кастрованого відгодованого півня). Третя страва - це була городина, наприклад, морква чи свіжа репа з олією. На 6 осіб ї̈ мало бути три великих одиниці, щоб на кожного припадало щонайменше по половині овочу. Четвертою стравою подавали ще якусь городину, наприклад квашену капусту чи свіжу, або ж горох із салом. Сир мав бути на столі завжди на обід і вечерю. Такими стравами харчувалися у будні, коли не було посту. Цебто у понеділок, вівторок і четвер. У неділю та у свята обов'язково готувалася п'ята страва: печений каплун або гуска, чи буженина або смажена свинина.

На особливі випадки виготовляли рід шампанського, що іменувалося «сектами». Серед шляхетних напоїв відзначалося угорське та французьке вино, що відносили до так званих «трунків знаменитих» (калькування з польської мови). Цебто до напоїв шляхетних, небуденних, урочистих ${ }^{9}$.

Наприкінці зали ставили буфет, заповнений дороговартісним срібним посудом гарної роботи, яку притримував поручень у формі невеличкої галереї. Тут зберігалося звичайно 8-10 стосів срібного посуду та стільки ж тарілок, що сягали зросту дорослих чоловіків. На такому прийомі найчастіше навпроти буфету, здебільшого над вхідними дверима, розташовувався театр зі сценою із музиками, що грали на різних музичних інструментах і співали. У першу чергу - грали на скрипках, згодом - на кларнетах ${ }^{10}$ (у цей час в українських селах найпопулярнішими музичними інструментами були дуда - рід волинки, скрипка, цимбали). Цікаво, що етикет застільної поведінки за спогадами де Боплана вже мав досить сформовану протокольну частину васально-господарської вертикалі.

На прийомах сенаторів накривали на столи та розставляли всілякі страви тоді, коли всі вже знаходилися на місці. Прислуговували на таких бенкетах по 4 шляхтичі, що стояли посеред зали, два з яких тримали срібні миски для миття посуду та дзбанки для обмивання рук присутніх із рушником. Розсадження запрошених здійснював господар відповідно до рангів і шляхетності (цебто витонченості, вишуканості, елегантності, знатності), гідності роду кожного. Обслуговування застілля покладалось на крайчих, яких було приставлено по 3 до кожного столу.

\section{Особливості господарського шику еліти тогочасного суспільства Галичини.}

Окремі матеріали реєстрів скарбових Жовкви на Львівщині - королівської резиденції Яна III Собеського кінця XVII ст. та маєтності його внучатого племінника Міхала Радзивілла Рибоньки середини XVIII ст. висвітлюють специфіку предметів для сервірування столу еліти тогочасного суспільства Галичини.

Серед іншого цікаво відзначити, що у королівсько-князівській кухні XVII ст. переважали форми для молока (кринки та горнятка), кави (філіжанки й кавники), штофи та кубки для пивної міцної наливки калдушалу. Останній напій був характерним для побуту білорусько-литовської верхівки суспільства, рецепт його на сьогодні втрачений. Однак за описами виробів, з яких прийнято було вживати калдушалу, швидше за все його виготов-

\footnotetext{
${ }^{9}$ Свербигуз В. Батурин: до генези українського самодержавства. Київ : Видавничий дім «Києво-Могилянська академія», 2008. 88 c.

${ }^{10}$ La Description d'Ukranie de Gullaume Le Vasseur de Beauplan...
} 
ляли як міцну високоградусну пивну настоянку. Крім того, протягом 1671-1745 pр. у Жовкві й Глинсько випускали ажурні кошики для фруктів, солодощів, хліба; горщики для перших і других страв, соусники, дзбанки, салатники, миски та полумиски, тарілки кількох фасонів, молочники, вершківниці, кавники, маснички, цукорниці, глеки, приземкуваті вази-жардиньєрки для квітів, світильники, пізніше - від 1765 р. цілі кавові сервізи, а згодом і чайники та грілки для них, умивальні пари, підігрівачі-ринки, цідильники, люлькистамбулки ${ }^{11}$. Відповідно означені ємності слугували для існуючих у побуті того часу наїдків і напоїв, вимог до чистоти тіла (традиції гігієни), аксесуарів для тютюну.

\section{Тенденції розвитку гайдамацько-козацької субкультури.}

У XVII-XVIII ст. на західноукраїнських землях, зокрема й на Правобережжі, повсюдно споживали квас, медовуху як прохолодні напої у всіх верствах суспільства, густу горілку «їли дерев'яними ложками» (збереглися такі куверти в експозиції Національного музею українського народного декоративного мистецтва) козаки, діжками споживали під час бенкетів у середовищі польсько-української шляхти, простий люд на щодень також вживав чаї 3 цілющих трав ${ }^{12}$.

Важливу роль у розвитку гайдамацько-козацької субкультури відігравав застільний етикет. Культура харчування неодружених запорожців (лицарів або товаришів) передбачала ранкове гаряче снідання після молитви, обід о 12 годині та вечерю. Їжу готували у котлах, насипали та подавали у невеликих дерев'яних ваганках (коритах), їли переважно дерев'яними ложками. Напої - мед, пиво, брагу, наливку, горілку наливали у великі дерев'яні коновки, до яких підвішувалися дерев'яні черпаки-коряки (ковші) або кухлі «михайлики» (вміст їх складав від трьох до п'яти об'ємів звичайних чарок - цебто 300500 мл). Під образами у покуті місце відводилося курінному отаману (всього їх було 37 за кількістю куренів) $)^{13}$.

Після вдалого завершення військових походів у козаків також було заведено влаштовувати гучні гуляння, що супроводжувалися рясною випивкою, безперебійними гарматними залпами, мушкетними пострілами, ходінням вулицями. Подібні урочистості стосувалися і різдвяних, великодніх свят, коли, крім іншого, було заведено вітати всю старшину з подарунками та гостинцями, учтиво випити із кошовим отаманом чарку горілки. 6 січня до цих святкувань приурочувався парад із хоругвами у кращому одязі й оздобленні коней, гарматний салют, народні гуляння після святкового богослужіння. Нерідко кінець цього святкового дня для звеселяння публіки закінчувався кулачними боями. У такі дні й рядові козаки інколи мали нагоду їсти срібними ложками і пити із срібних чарок ${ }^{14}$.

До січових запорожців у свята приєднувалися і посполиті - козаки, що мешкали із родинами у зимівниках, так звані «гнездюки». Цей прошарок населення був підданим січовим козакам, займався вирощуванням круп (передусім пшона, гречки), хліба, овочів, фруктів тощо, які закуповувалися до кошів. «Боголюби», як іменувалися сидньові козаками під час оголошення підготовки до війни скликалися гінцями-машталірами, а у мир-

\footnotetext{
${ }^{11}$ Яворницький Д. Історія запорозьких козаків. У 3-х т. Т. 1. Київ: Наук. думка. 1990. 583 с.

${ }^{12}$ Андреев В.Ф. Золотая книга этикета. Москва: Вече, 2004. 400 с.

${ }^{13}$ Яворницький Д. Історія запорозьких козаків. Т. 1... С. 45.

${ }^{14}$ Яворницький Д. Історія запорозьких козаків. Т. 1... С. 130.
} 
ний час розводили худобу, займалися бджільництвом, сіллю, ловами риби, раків, дичини, що складала частину культури харчування запорожців ${ }^{15}$.

Про стосунки між громадянами де Боплан свідчив, що люд тут «тонкий і проникливий, винахідливий і щедрий, без наміру й амбіцій стати багатим»; «високий на зріст, жвавий та енергійний, любить гарно вдягатися» ${ }^{16}$. Одяг вже тоді для русинів-українців мав значення індикатору заможності та добробуту, а нечисельна місцева шляхта (вельможі та князі), за свідченням Г. де Боплана, сповідували грецьку віру, хоча із цікавістю слідкували і за прихильниками віри латинської.

Поступово козацтво сформувало власну військову моду, відмінну від одягу країн оточення, а у добу барокової культури асимільовану одночасно з турецько-татарськими ментальними впливами, що тяглися ще від печенігів-половців, та, одночасно кавказьких і сарматських звичаїв. Останні впливи суттєво трансформувалися у другій-третій третинах XVIII ст., що віддзеркалювалося у істотних змінах етикету, церемоніалу та протоколу між нобілітетом етнічних України та Польщі.

\section{Висновки.}

Таким чином, у козацькому середовищі поступово склалися певні церемонії, які стосувалися релігійних відправ або свят, ініціацій і перетрактацій. Оскільки козаки стали окремим соціальним прошарком, і до середини - третьої чверті XVIII ст. розпорошилися по різних містах Лівобережжя та Правобережжя України, їхні звички, традиційне право, вимоги до чеснот і добропорядності, етики, етикету, життєвої філософії поширилися широко за межами Запорожжя та Хортиці. Козацький світогляд, менталітет, звитяжна праця в ім'я захисту своєї Батьківщини спричинили певну моду на їх уклад життя, що вважався у староукраїнській культурі звитяжним, гідним, традиційним. Відповідно з часом селянське, міщанське, купецьке, військово-чиновниче населення, а також окремі шляхтичі, дотичні до спілкування з козацьким генералітетом, запозичили низку звичаїв останніх, що поступово влилися у світський етикет, відобразився на культурі харчування, поводження у суспільстві.

Новизною нашого дослідження є констатування факту, що зростання національної самосвідомості українців зумовлене, з одного боку, етнічним розвитком, зіткненням 3 іноетнічним населенням Речі Посполитої, а з іншого - знайомством з гуманістичними концепціями гайдамацько-козацької субкультури, що, у свою чергу, викликало інтерес до свого походження представників різних верств українського населення. Особливими пріоритетами чого, на кінець XVII-XVIII ст. вирізнявся етикет спілкування різних верств населення (обрядова, майданна та сміхова мова). Особливо вирізнялися традиційні святкові обороти та примовки, пов'язані із ритуалами гостин (ходили тільки дорослі без дітей), пригощання, почастунків.

Перспективи подальших досліджень полягають у розкритті освітянських культурологічних тенденцій ментальності українського народу доби XVII ст.

\footnotetext{
${ }^{15}$ Яворницький Д. Історія запорозьких козаків. Т. 1... С. 250.

${ }^{16}$ Барвінський Б. «Україна» Боплана // Стара Україна. 1924. № 1. С. 14.
} 


\title{
Liliia Horodynska
}

\section{Development of traditions, customs and beginnings of etiquette of different layers of the Ukrainian population in the XVII century}

\begin{abstract}
The article deals with the coverage of traditions, customs and the beginnings of etiquette of different segments of the Ukrainian population of the seventeenth century. in terms of revealing the nation-building potential of Ukrainians. The substantiation of noble Ukrainian studies essays by the French cartographer Guillaume de Beauplan shows the life of the population at that time. The peculiarities of the economic chic of the elite of the Galician society of that time are characterized. Trends in the development of the Haydamat-Cossack subculture are revealed. The mental portrait of the Ukrainian intelligentsia is described, which embodied a set of traditions, customs and culturological tendencies of different strata of the Ukrainian population of the 17th century.

Based on the work of predecessors, a broad source base and modern methodological approaches, the aim of the article is a comprehensive coverage of traditions, customs and the beginnings of etiquette of different segments of the Ukrainian population of the seventeenth century. in terms of revealing the nation-building potential of Ukrainians.

In the Cossack environment, certain ceremonies gradually took place, which concerned religious services or holidays, initiations and retractions. As the Cossacks became a separate social stratum, and by the middle - the third quarter of the eighteenth century. scattered in different cities of the Left Bank and the Right Bank of Ukraine, their habits, traditional law, requirements for virtue and decency, ethics, etiquette, philosophy of life spread widely outside of Zaporozhye and Khortytsia. The Cossack worldview, mentality, and victorious work in the name of defending their Motherland caused a certain fashion for their way of life, which was considered victorious, dignified, and traditional in the old Ukrainian culture. Over time, the peasant, bourgeois, merchant, military and bureaucratic population, as well as some nobles involved in communication with the Cossack generals, borrowed a number of customs of the latter, which gradually merged into secular etiquette, reflected in the culture of food, behavior in society.
\end{abstract}

Keywords: traditions, customs, etiquette of the Ukrainian population, $17^{\text {th }}$ century, life of a Cossack elder, church elite, secular etiquette of Galicia 